New Developments in Sheep Production

Occasional Publication No. 14-British Society of Animal Production 1990

edited by C. F. R. Slade and T. L. J. Lawrence

\title{
THE RESPONSES OF SILAGE-FED SCOTTISH BLACKFACE LAMBS TO INCREASING LEVELS OF FISH MEAL SUPPLEMENTATION WITH OR WITHOUT ADDITIONAL BARLEY
}

\author{
GILLIAN M. POVEY', G. M. WEBSTER ${ }^{1}$ and T. E. C. WEEKES ${ }^{2}$ \\ 'Department of Agriculture, The University, Newcastle upon Tyne NEI 7RU \\ ${ }^{2}$ Department of Agricultural Biochemistry and Nutrition, The University, Newcastle upon Tyne NE1 7RU
}

\section{INTRODUCTION}

$\mathbf{T}$ he use of silage-based diets to finish store lambs indoors has often produced variable results in terms of food intake, growth rate and carcass quality. Good quality silage is required to maximize voluntary intake but live-weight gains on silage alone are generally low (Reed, 1979). Cereal supplements have been shown to improve lamb performance at the expense of silage intake, while protein supplementation has been found to improve lamb performance and generally increase silage intake (Yilala and Bryant, 1985). The experiment described here investigated the performance responses of silage-fed hill lambs to a wide range of fish meal levels offered with or without additional barley after a period of maintenance feeding. It extends previous work (Povey, Webster and Weekes, 1989) in which linear growth responses to increasing levels of fish meal up to $75 \mathrm{~g}$ fresh weight (FW) per head per day were found.

\section{MATERIAL AND METHODS}

Sixty-four Scottish Blackface wether lambs, aged 5 months, born and reared as singles and weighing $26 \cdot 3$ (s.e. 0.23 ) $\mathrm{kg}$ at the start of the experiment were used. They were allocated to one of sixteen treatment groups on the basis of similar mean live weight and condition score per group. Each group of four lambs was offered silage ad libitum plus one of eight levels of fish meal, either with or without whole barley, in a factorial design. The levels of barley and fish meal are shown in Table 1. The supplemented diets were given to the lambs for a period of up to 10 weeks after a 4-week store period during which they received ad libitum silage alone. The 14-week experimental period lasted from September to December 1988.

\section{Lamb management and housing}

The lambs were obtained from Redesdale Experimental Husbandry Farm in Northumberland immediately after weaning off hill pasture at the end of August. They were housed on arrival at the University farm, were wormed, and vaccinated against clostridial and pasteurella diseases. Feeding of silage began immediately. Each group of four lambs was kept in a pen of dimensions $1.4 \times 2.7 \mathrm{~m}$ which allowed each lamb $0.35 \mathrm{~m}$ trough space. The lambs were bedded on straw and had continual access to fresh water and mineral licks. Treatment diets were randomly allocated to each pen and the photoperiod was maintained at $14 \mathrm{~h}$ light : $10 \mathrm{~h}$ dark by artificial lighting to remove any confounding effects of daylength on food intake and growth rate.

\section{Foodstuffs}

Silage was made from the first cutting of a predominantly perennial ryegrass sward which had been allowed to wilt for $24 \mathrm{~h}$. On collection, the grass was precision chopped and treated with formic acid (Add-F, BP Nutrition Ltd), at a rate of 3 to $4 \mathrm{l} / \mathrm{t} \mathrm{FW}$, before ensiling. Silage samples were collected every 7 to 10 days during the experiment and the mean analysis of these is shown in Table 2 . The supplements were given daily on top of the silage ration for each pen of lambs. The fish meal had a dry matter (DM) content of $907 \mathrm{~g} / \mathrm{kg} \mathrm{FW}$ and a crude protein content of $676 \mathrm{~g} / \mathrm{kg} \mathrm{DM}$.

TABLE 1

Levels of supplements ( $g$ fresh weight per head per day) given to lambs

Whole barley

$\begin{array}{ccccccccc}0 & 0 & 20 & 40 & 60 & 80 & 100 & 120 & 140 \\ 350 & 0 & 20 & 40 & 60 & 80 & 100 & 120 & 140\end{array}$




\section{Measurements}

Lambs were group-fed silage ad libitum with refusals measured daily during both the store and finishing periods. To ensure ad libitum intake, proportionately $0 \cdot 10$ more silage was offered to each pen of lambs than had been eaten the previous day. Daily silage DM intake for each pen was calculated using the analysis of each weekly silage sample. Lambs were weighed and assessed for condition weekly by subjective handling of the loin area. They were selected for slaughter at an estimated Meat and Livestock Commission (MLC) fat score of 2 to $3 \mathrm{~L}$; unfinished lambs were slaughtered at the end of the experiment. Final live weight was recorded on the day of slaughter and dead weight and MLC carcass classification data were obtained from the abattoir.

\section{Statistical analysis}

The mean daily silage DM intake for each group of lambs was calculated and expressed per lamb; total DM intake was calculated using the DM values of the supplements. The daily live-weight gain of each lamb over the finishing period was determined by linear

TABLE 2

Silage analysis (12 samples)

$\begin{array}{lcl}\text { Dry matter (g/kg fresh weight) } & 209 & 6 \cdot 2 \\ \text { Ash (g/kg DM) } & 91 & 2 \cdot 2 \\ \mathrm{pH} & 4 \cdot 0 & 0 \cdot 04 \\ \text { Crude protein (g/kg DM) } & 155 & 4 \cdot 1 \\ \text { Ammonia nitrogen (g/kg total N) } & 52 & 6 \cdot 3 \\ \text { MAD fibre (g/kg DM) } & 365 & 4 \cdot 7 \\ \text { Estimated D value } & 61 \cdot 2 & 0 \cdot 40 \\ \text { Metabolizable energy (MJ/kg DM) } & 9 \cdot 8 & 0 \cdot 07 \\ \text { Digestible crude protein (g/kg DM) } & 104 & 3 \cdot 8\end{array}$

regression. Growth and carcass data were subjected to analysis of variance by energy and protein level using the SPSSx program (Statistical Package for the Social Sciences Inc., 1986). The growth responses of lambs to increasing levels of fish meal were fitted using orthogonal polynomial contrasts (Ridgman, 1975).

\section{RESULTS}

The silage intake of the lambs during the final 2 weeks of the store period (over which it was measured) was $556 \mathrm{~g}$ DM per head per day. Their live weight at the end of the store period was $28 \cdot 8$ (s.e. $0 \cdot 30$ ) $\mathrm{kg}$ indicating a slight increase over the 4-week store period. The intake and performance data of lambs during the finishing period are shown in Table 3 . Inclusion of barley in the diets was found to decrease silage intake but increase total food intake and significantly increase daily live-weight gain compared with diets without barley $(P<0 \cdot 001)$. There was no clear effect of fish meal on silage intake but increasing levels of the protein supplement tended to increase total food intake and improve the food conversion ratio of the lambs with a significant improvement in daily live-weight gain $(P<0.001)$.

The effects of increasing levels of fish meal supplementation on silage intake and daily live-weight gain when offered with or without additional barley are shown in Figures 1 and 2 respectively. In both cases, there was a significant linear increase in daily live-weight gain with increasing inclusion of fish meal in the diet $(P<0 \cdot 001)$. However, in lambs given high levels of fish meal without additional barley, responses were quite variable (Figure 2), and lambs offered fish meal at $120 \mathrm{~g}$ FW per head per day were also observed refusing the supplement.

By the end of the experimental period, only three lambs remained unfinished and these were from

TABLE 3

Effect of level of barley and fish meal on food intake and lamb performance

Level of barley ( $g$ fresh weight per head per day)

$\overbrace{0}^{350}$

\footnotetext{
Silage intake (g DM per head per day)

Total intake (g DM per head per day)

Daily live-weight gain (g per head)

s.e.d. ( 47 d.f.)

and significance

Food conversion ratio
}

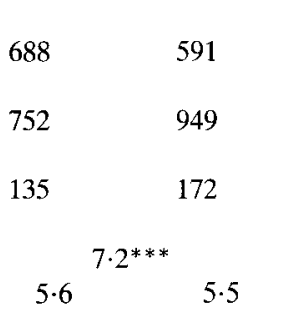

Level of fish meal ( $g$ fresh weight per head per day)

\begin{tabular}{rrrrrrrrr}
\hline 0 & 20 & 40 & 60 & 80 & 100 & 120 & 140 \\
654 & 654 & 594 & 656 & 654 & 639 & 616 & 652 \\
801 & 819 & 777 & 857 & 874 & 877 & 872 & 926 \\
132 & 125 & 139 & 161 & 156 & 177 & 150 & 184 \\
& & & & & & & & \\
6.1 & 6.6 & 5.6 & 5.3 & $5 \cdot 6$ & 4.9 & 5.8 & 5.0
\end{tabular}




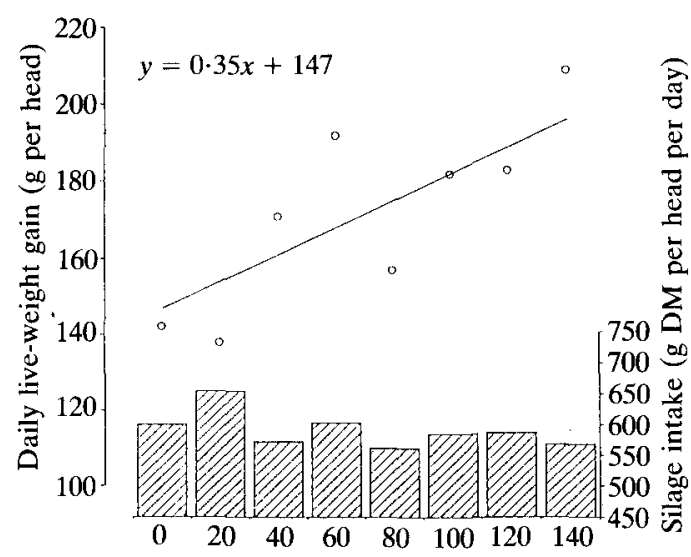

Level of fish meal (g FW per head per day)

FIG. 1. Responses of lambs to increasing levels of fish meal with additional barley $(350 \mathrm{~g} \mathrm{FW}$ per head per day).

treatment groups receiving no barley supplement. The effects of level of barley and fish meal inclusion on the carcass characteristics of finished lambs are shown in Table 4. There were no significant differences in MLC fat classification between groups, confirming that all lambs had been slaughtered at the same degree of finish. Inclusion of barley significantly increased final live weight $(P<0.05)$, dead weight $(P<0.001)$ and killingout proportion $(P<0.05)$ and, although not significant, these variables also tended to increase with increasing level of fish meal.

\section{DISCUSSION}

The silage used in this experiment was well fermented and preserved, as indicated by the low $\mathrm{pH}$ and ammonia nitrogen levels, but its $\mathrm{D}$ value and metabolizable energy content were relatively low. Nevertheless, all rations, including silage alone, provided energy and protein in excess of the requirements for maintenance (Agricultural Research Council (ARC), 1980), as indicated by the growth of lambs during the store period.

Barley is a common cereal energy source and was given whole in this experiment since it has been found to maintain a higher and more stable rumen $\mathrm{pH}$ and improve carcass characteristics compared with processed barley ( $\varnothing$ rskov, 1987). The improvement in total food intake at the expense of silage intake which was observed has also been reported by Fitzgerald (1983)

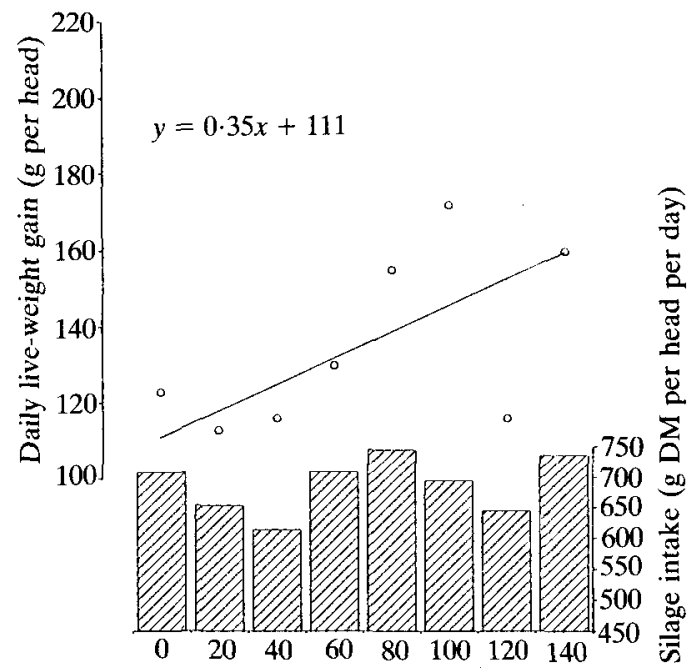

Level of fish meal ( $\mathrm{g}$ FW per head per day)

FIG. 2. Responses of lambs to increasing levels of fish meal without additional barley.

TABLE 4

Effect of level of barley and fish meal on carcass characteristics of finished lambs

Level of barley ( $\mathrm{g}$ fresh weight per head per day)

No. of lambs

Final live weight $(\mathrm{kg})$

s.e.d (44 d.f.) and signficance

Dead weight $(\mathrm{kg})$

s.e.d. ( 44 d.f.) and significance

Killing-out proportion $(\mathrm{g} / \mathrm{kg})$

s.e.d. (44 d.f.) and significance

MLC fat classification

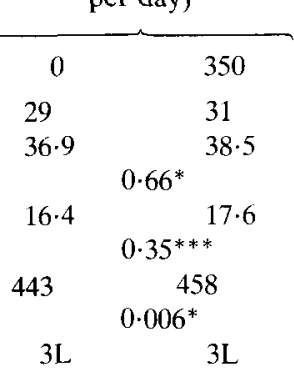

Level of fish meal

( $g$ fresh weight per head per day)

\begin{tabular}{cccccccc}
\hline 0 & 20 & 40 & 60 & 80 & 100 & 120 & 140 \\
7 & 8 & 6 & 8 & 8 & 7 & 8 & 8
\end{tabular}

$\begin{array}{llllllll}36 \cdot 6 & 36 \cdot 1 & 37 \cdot 0 & 38 \cdot 6 & 38 \cdot 3 & 38 \cdot 4 & 37 \cdot 3 & 39 \cdot 2\end{array}$

$\begin{array}{lll}1.32 & \end{array}$

$\begin{array}{cccccccc}16 \cdot 4 & 16 \cdot 2 & 16 \cdot 7 & 17 \cdot 0 & 17 \cdot 3 & 17 \cdot 1 & 17 \cdot 3 & 17 \cdot 9 \\ 447 & 447 & 450 & \begin{array}{l}0 \cdot 70 \\ 442\end{array} \\ & & 452 & 448 & 464 & 455\end{array}$

$\begin{array}{llllllll}3 \mathrm{~L} & 3 \mathrm{~L} & 3 \mathrm{~L} & 2 & 3 \mathrm{~L} & 3 \mathrm{~L} & 3 \mathrm{~L} & 3 \mathrm{~L}\end{array}$ 
and Yilala and Bryant (1985). The effect of barley supplementation on silage intake depends on a number of factors including the type and maturity of the silage, the initial level of silage intake when offered alone and the level of barley offered (Fitzgerald, 1987). Fitzgerald (1986) found that feeding barley to lambs at $500 \mathrm{~g} \mathrm{FW}$ per head per day reduced silage intake while at levels of $250 \mathrm{~g}$ FW per head per day, silage intake was not affected. In the present experiment, a level of $350 \mathrm{~g} \mathrm{FW}$ barley per head per day was chosen since this appeared to be the optimum in terms of lamb growth responses in previous work by Povey et al. (1989). The rapid fermentation of the cereal in the rumen, thereby creating an unfavourable environment for the growth of cellulolytic bacteria (Kelly and Thomas, 1978), probably contributed to the reduced silage intake.

The improved daily live-weight gain associated with barley inclusion was clearly a direct result of increased metabolizable energy intake. Inclusion of barley may also have led to an increased proportion of digestible energy and organic matter being digested in the small intestine, and to an increased passage of glucose polymers to the duodenum (Thomas, Kelly, Chamberlain and Wait, 1980). Cereal supplementation has also been shown to increase microbial synthesis and reduce ammonia concentration in the rumen, and increase nitrogen retention (Gill and Ulyatt, 1977; Yilala and Bryant, 1985).

The lack of any consistent effect of fish meal on silage intake has been reported previously by Stone and Appleton (1984) and Hughes and Mansbridge (1986). Yilala and Bryant (1985) found improvements in silage intake with fish meal supplementation but reported that the effect was dependent on the level offered. The improvement in daily live-weight gain with increasing levels of fish meal is in accord with the findings of Tayer and Bryant (1988) who proposed that the efficiency of utilization of nutrients in the rumen was improved. In the current experiment there was certainly an improvement in the food conversion ratio with increasing fish meal inclusion, thereby supporting this concept.

Fish meal offers a rich supply of rumen undegradable protein (UDP) and has been found to increase nitrogen retention (Hassan and Bryant, 1986). However, the linear growth responses up to the highest level of fish meal offered ( $140 \mathrm{~g}$ FW per head per day) were unexpected, particularly since ARC (1980) predicted that a source of UDP is unnecessary in lambs over $30 \mathrm{~kg}$. More recently, it has been suggested that lambs become protein depleted during a period of maintenance feeding and that in such circumstances they will subsequently respond to UDP (Ørskov, 1987). This, in part, may explain the significant responses observed. However, at high levels of fish meal it is possible that the lambs used the excess supplement as an energy source once their protein requirements had been met. This concept is supported by changes in blood metabolites that were observed (G. M. Povey, T. E. C. Weekes and G. M. Webster, unpublished). In any event, such high levels of fish meal supplementation are likely to be uneconomic and palatability problems may arise.

The inclusion of barley in the diet produced heavier lambs at slaughter with increased killing-out proportions. Black (1983) reviewed the effects of nutrition on body composition of lambs, concluding that high energy diets resulted in increased body fat at similar weights. Thus, lambs given barley would have been expected to be lighter at the same MLC classification than those given diets without barley. However, since the growth rates measured in this experiment were relatively low, it is unlikely that the level of barley offered was sufficient to cause excessive fat deposition; rather that it promoted efficient utilization of nutrients for growth. Similarly, the trend for improved carcass weights with increasing levels of fish meal suggests a requirement for protein above that available from silage alone, at least at lower levels of inclusion.

\section{ACKNOWLEDGEMENTS}

The technical assistance of Mr S. R. Oliver and the financial support of the Ministry of Agriculture, Fisheries and Food is gratefully acknowledged.

\section{REFERENCES}

Agricultural Research Council. 1980. The Nutrient Requirements of Ruminant Livestock. Commonwealth Agricultural Bureaux, Slough.

BLACK, J. L. 1983. Growth and development of lambs. In Sheep Production (ed. W. Haresign), pp. 21-58. Butterworths, London.

Fitzgerald, S. 1983. Effect of type of roughage and barley supplementation on the performance of store lambs. Animal Production Research Report, pp. 75. An Forus Talúntais, Dublin.

Fitzgerald, J. J. 1986. Finishing of store lambs on silage-based diets. 3. Effects of formic acid with or without formaldehyde as silage additives and barley supplementation on silage intake and lamb performance. Irish Journal of Agricultural Research 25: 363-377.

Fitzgerald, J. J. 1987. Finishing store lambs on silage-based diets. 4. Effects of stage of grass growth when ensiled and barley supplementation on silage intake and lamb performance. Irish Journal of Agricultural Research 26: 139-151.

Gill, M. and UlyatT, M. J. 1977. The effect of supplementation with protein, energy and Lmethionine on the digestion of silage by sheep. 
Journal of Agricultural Science, Cambridge 89: 43-51.

Hassan, S. A. and Bryant, M. J. 1986. The response of store lambs to dietary supplements of fish meal. 2 . Effects of level of feeding. Animal Production 42: 233-240.

Hughes, G. J. and Mansbridge, R. J. 1986. The effect of supplementing silage with fish meal for finishing store lambs. Animal Production 42: 454 (Abstr.).

Kelly, N. C. and Thomas, P. C. 1978. The nutritive value of silages. Energy metabolism of sheep receiving diets of grass silage or grass silage and barley. British Journal of Nutrition 40: 205-219.

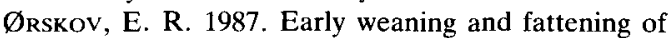
lambs. In New Techniques in Sheep Production (ed. I. F. M. Marai and J. B. Owen), pp. 189-195. Butterworths, London.

Povey, G. M., Webster, G. M. and Weekes, T. E. C. 1989. The response of silage-fed Scottish Blackface lambs to different levels of energy and protein supplementation with or without a store period. Animal Production 48: 645 (Abstr.).

REED, K. F. M. 1979. A note on the feeding value of grass and grass/clover silages for store lambs. Animal Production 28: 271-274.
Ridgman, W. R. 1975. Experimentation in Biology, Blackie, London.

Statistical Package for the Social Sciences Inc. 1986. SPSSx User's Guide, 2nd ed. McGraw-Hill, New York.

Stone, C. and Appleton, M. 1984. The effect of silage dry matter concentration and protein supplementation on the intake and performance of housed store lambs. Animal Production 38: 522 (Abstr.).

TAYER, S. R. and BRYANT, M. J. 1988. The response of store lambs to dietary supplements of fish meal. 3 . Effects of the preceding pattern of growth. Animal Production 47: 393-399.

Thomas, P. C., Kelly, N. C., Chamberlain, D. G. and WAIT, M. K. 1980. The nutritive value of silages. Digestion of organic matter, gross energy and carbohydrate constituents in the rumen and intestines of sheep receiving diets of grass silage or grass and barley. British Journal of Nutrition 43: 481-489.

Yilala, K. and Bryant, M. J. 1985. The effects upon the intake and performance of store lambs of supplementing grass silage with barley, fish meal and rapeseed meal. Animal Production 40: 111121. 